\title{
Preferensi Pemerintah terhadap Pengembangan Ruang Terbuka Hijau Publik di Kota Malang Melalui Program Corporate Social Responsibility (CSR)
}

\author{
Auliyaa Syara Diinillah dan Haryo Sulistyarso \\ Departemen Perencanaan Wilayah dan Kota, Fakultas Teknik Sipil dan Perencanaan, Institut Teknologi \\ Sepuluh Nopember (ITS) \\ e-mail: haryo.its@gmail.com
}

\begin{abstract}
Abstrak-Kota Malang memiliki presentase RTH publik yang belum memenuhi proporsi minimal RTH publik $20 \%$. Salah satu penyebabnya adalah karena Pemerintah Kota Malang memiliki kendala keterbatasan dana APBD dalam hal pembangunan RTH publik, sehingga menjalin kerjasama dengan sejumlah pihak swasta melalui program Corporate Social Responsibility (CSR). Agar program CSR dari pihak swasta sesuai dengan kebutuhan pemerintah, maka diperlukan penelitian yang bertujuan untuk mengetahui preferensi Pemerintah Kota Malang terhadap pengembangan RTH publik melalui program. Preferensi terhadap pengembangan RTH publik ini ditentukan dengan menggunakan teknik content analysis. Teknik ini dilakukan dengan cara mengandalkan kode-kode yang ditemukan dalam sebuah teks perekaman data selama wawancara dilakukan dengan responden penelitian. Hasil dari penelitian ini adalah preferensi pemerintah terhadap pengembangan RTH publik di Kota Malang yang terbagi atas 3 aspek, yaitu aspek lingkungan, ekonomi, dan sosial. Dari aspek lingkungan adalah jenis hutan kota, taman kota, dan jalur hijau yang dapat dikembangkan pada lokasi potensial dipinggir Kota Malang dengan mempertimbangkan tematik pengembangan, fungsi ekologis, fungsi sosial budaya, fungsi edukatif dan fungsi estetika serta sesuai dengan aturan tata ruang yang berlaku. Dari aspek ekonomi maka bentuk bantuan yang dibutuhkan berupa pembangunan fisik RTH publik melalui mekanisme penyelenggaraan program CSR yang ada dan dilakukan oleh perusahaan yang memiliki visi dan misi dibidang lingkungan. Dari aspek sosial maka dalam merumuskan program CSR perlu peran aktif masyarakat seperti tokoh masyarakat setempat, akademisi, komunitas serta program CSR perlu dipublikasikan sebagai wujud branding Kota Malang dan stimulasi pihak swasta lain untuk terlibat.
\end{abstract}

Kata Kunci-Ruang Terbuka Hijau Publik, Corporate Social Responsibility (CSR), Content Analysis.

\section{PENDAHULUAN}

$\mathrm{R}$ UANG Terbuka Hijau sebagai salah satu ruang publik di perkotaan harus memiliki luasan minimal yang ideal yaitu $30 \%$ dari luas total suatu wilayah kota, terdiri dari $20 \% \mathrm{RTH}$ publik dan $10 \%$ RTH privat [1]. Dalam penyediaan dan pemanfaatan RTH dibutuhkan peran dari pihak swasta seperti bekerjasama dengan pemerintah dan masyarakat dalam membangun dan memelihara ruang terbuka hijau serta mengupayakan bantuan pendanaan bagi masyarakat dalam realisasi pelibatan dalam pemanfaatan dan pemeliharaan ruang terbuka hijau [2]. Salah satu bentuk peran dari pihak swasta adalah adanya penyediaan melalui program CSR. Kebijakan mengenai CSR tersebut telah diatur dalam UU Nomor 40 Tahun 2007 tentang Perseroan Terbatas, dimana perseroan yang menjalankan kegiatan usahanya dibidang dan/atau berkaitan dengan sumber daya alam wajib melaksanakan Tanggung Jawab Sosial dan Lingkungan [3].

Pada tahun 2016 jumlah luasan RTH publik di Kota Malang masih sebesar 1.362,32 $\mathrm{Ha}$ atau sama dengan 12,38\% dari luas total wilayah Kota Malang yaitu sebesar 11.006 Ha yang seharusnya mencadangkan 2.201,2 Ha untuk RTH publik 20\% [4]. Berdasarkan hasil wawancara dengan Kepala Seksi Taman DPKP Kota Malang pada Februari 2017, Pemerintah Kota Malang memiliki kendala keterbatasan dana APBD dalam hal pembangunan RTH publik, sehingga Pemerintah Kota Malang menjalin kerjasama dengan sejumlah perusahaan melalui program Corporate Social Responsibility (CSR).

Dalam kurun waktu tahun 2011-2017 telah dilaksanakannya 16 program CSR, diantaranya adalah revitalisasi Taman Slamet (CSR dari PT. Bentoel Prima), revitalisasi Alun-Alun Merdeka Kota Malang (CSR dari BRI), penataan kawasan pedestrian di Jl. Ijen, dan lain sebagainya. Dari pelaksanaan yang sudah ada, Pemerintah Kota Malang menilai bahwa persebaran RTH publik yang dikembangkan melalui program CSR belum merata, karena hanya terpusat pada Kecamatan Klojen yang merupakan pusat Kota Malang [5]. Dalam pelaksanaannya, kewenangan persetujuan CSR dilakukan secara kesepakatan bersama antara pemberi dengan penerima CSR yaitu SKPD Pemerintah Kota Malang tanpa campur tangan pihak lain.

Untuk dapat menentukan bentuk bantuan yang sesuai dengan kebutuhan pemerintah, pihak swasta perlu mengetahui kebutuhan pengembangan RTH publik berdasarkan preferensi pemerintah. Maka dari itu diperlukan penentuan preferensi pemerintah terhadap pengembangan RTH publik di Kota Malang melalui program CSR, agar dapat memberikan informasi kepada pihak swasta untuk merumuskan program CSR agar berjalan sesuai dengan kebutuhan dari Pemerintah 
Kota Malang.

\section{METODE PENELITIAN}

\section{A. Metode Pengumpulan Data}

Metode pengumpulan data yang digunakan dalam penelitian ini adalah teknik survei primer dan sekunder. Mayoritas data yang diperlukan dalam penelitian ini merupakan data primer yang diperoleh dari hasil pengamatan secara langsung (Observasi Lapangan) dan wawancara dengan menggunakan teknik in-depth interview kepada responden terpilih dari stakeholder pemerintah. Penentuan responden wawancara dilakukan analisis stakeholder dengan memetakan kepentingan dan pengaruh dari stakeholder terkait, sehingga didapatkan 2 instansi yang menjadi responden wawancara yaitu Dinas Perumahan dan Kawasan Permukiman Kota Malang dan Badan Perencanaan, Penelitian, dan Pengembangan (Barenlitbang) Kota Malang.

Sedangkan untuk data sekunder digunakan sebagai pelengkap data-data primer yang telah didapatkan. Metode pengumpulan data sekunder dalam penelitian ini adalah studi pustaka dan survei instansi untuk memperoleh gambaran umum wilayah, peraturan daerah terkait pengembangan RTH publik, dasar-dasar teori dan konsep serta penerapan (best practices) pengembangan RTH publik melalui program CSR.

\section{B. Metode Analisis}

Untuk menentukan kebutuhan pengembangan RTH publik melalui program CSR digunakan teknik analisis content analysis. Content analysis merupakan analisis yang mengandalkan kode-kode yang ditemukan dalam sebuah teks perekaman data selama wawancara dilakukan dengan responden penelitian [6]. Content analysis dilakukan dengan tujuan untuk mengeksplorasi kebutuhan pengembangan RTH publik di Kota Malang melalui program CSR. Analisis yang dilakukan mengacu pada variabel penelitian hasil sintesa pustaka yang terdiri atas variabel lokasi RTH publik, jenis RTH publik, fungsi RTH publik, tematik pengembangan RTH publik, bentuk bantuan CSR dalam RTH publik, jangka waktu pemeliharaan RTH publik, mekanisme penyelenggaraan program CSR, bentuk pendekatan pemerintah, kesesuaian program CSR dengan perusahaan, bentuk insentif kerjasama, dampak program CSR terhadap perusahaan, ketersediaan media promosi perusahaan dalam RTH publik, keterlibatan masyarakat dalam program CSR, dan ketersediaan media publikasi program CSR.

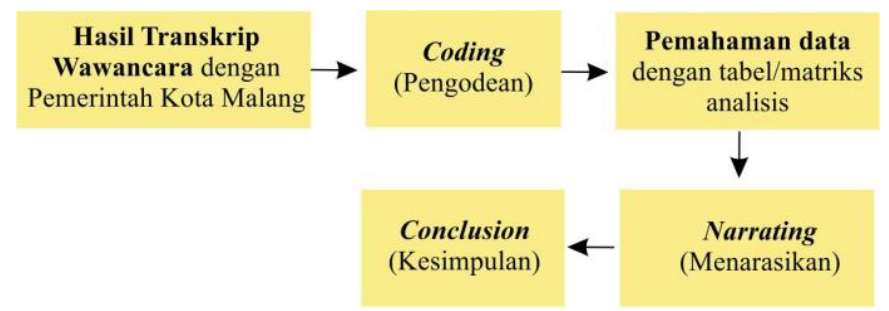

Gambar 1. Ilustrasi Alur Proses Content Analysis.

Sumber : Bungin (2010) diolah.

\section{HASIL DAN PEMBAHASAN}

Untuk dapat menentukan preferensi Pemerintah Kota Malang terhadap pengembangan RTH publik melalui program CSR berdasarkan preferensi Pemerintah Kota Malang dilakukan wawancara in-depth interview.

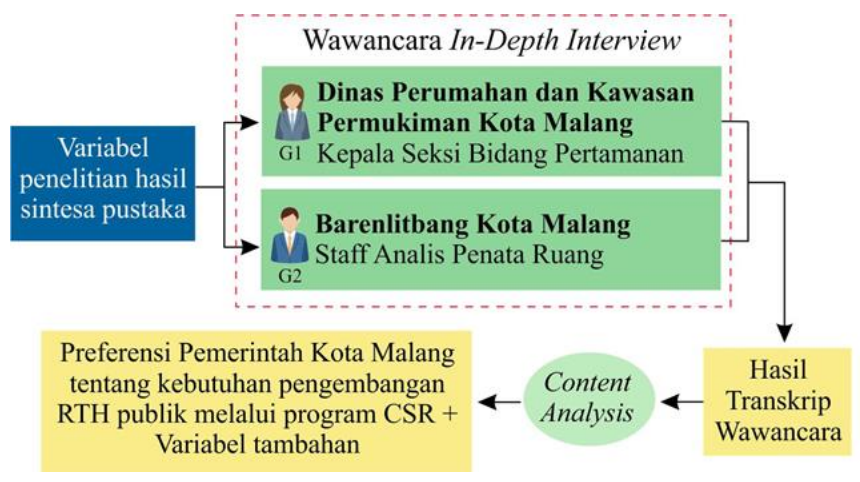

Gambar 2. Bagan Alur Penelitian.

Sumber : Penulis, 2017.

Berdasarkan bagan pada Gambar 2 diatas, dapat dilihat bahwa dalam menentukan faktor-faktor kebutuhan pengembangan RTH publik maka dilakukan :

1. Wawancara In-Depth Interview kepada Responden Penelitian

Wawancara ini dilakukan dengan menggunakan teknik In-depth interview dan dilakukan kepada 2 responden dari kelompok pemerintah (governance) yang meliputi Dinas Perumahan dan Kawasan Permukiman Kota Malang dan Badan Perencanaan, Penelitian, dan Pengembangan Kota Malang. Daftar pertanyaan yang diajukan dalam wawancara ini mengacu pada variabel penelitian yang didapatkan dari hasil sintesa pustaka.

2. Analisis dengan Metode Content Analysis

Dari hasil wawancara dengan responden penelitian dilakukan penulisan transkrip wawancara sebagai bahan untuk dianalisis menggunakan teknik analisis content analysis. Selanjutnya, ditentukan kode pada hasil transkrip wawancara berdasarkan masing-masing variabel penelitian.

Tabel 1.

Daftar Kode Variabel Penelitian

\begin{tabular}{cll}
\hline \hline Angka & Warna & \multicolumn{1}{c}{ Variabel Penelitian (Kode : C) } \\
1 & & Lokasi RTH publik \\
2 & & Jenis RTH publik \\
3 & & Fungsi RTH publik \\
4 & Tematik pengembangan RTH publik \\
5 & & Jangka waktu pemeliharaan RTH publik \\
6 & Bentuk Bantuan CSR \\
7 & Mekanisme penyelenggaraan program CSR \\
8 & Bentuk pendekatan pemerintah \\
9 & Kesesuaian program CSR dengan perusahaan \\
10 & Bentuk insentif kerjasama \\
11 & Dampak program CSR terhadap perusahaan \\
12. & Ketersediaan media promosi perusahaan dalam \\
13. & RTH publik \\
14. & Keterlibatan masyarakat \\
\hline \hline Sumber : Penulis, 2017 &
\end{tabular}

Setelah dilakukan pengodean (coding), dilakukan pemahaman data dengan menggunakan tabel/matriks analisis yang berisi kesimpulan dari preferensi masing-masing responden terhadap suatu variabel penelitian dengan dilengkapi 
transkrip responden yang menjelaskan tentang suatu variabel.

\begin{tabular}{|c|c|c|c|c|c|}
\hline \multirow{2}{*}{ Variabel } & \multirow{2}{*}{$\begin{array}{l}\text { Stake } \\
\text { holder }\end{array}$} & \multicolumn{3}{|c|}{ Pemahaman Data Transkrip } & \multirow{2}{*}{ Analisis } \\
\hline & & Transkrip & Kode & Hasil & \\
\hline $\begin{array}{l}\text { Lokasi RTH } \\
\text { publik }\end{array}$ & G1 & $\begin{array}{l}\text { "Kalo misalnya } \\
\text { dalam rangka } \\
\text { CSR ya, ittu } \\
\text { relevan. Pasti } \\
\text { dia } \\
\text { diancari } \\
\text { yang intensitas } \\
\text { pengunjung } \\
\text { yang } \\
\text { menikmatinya } \\
\text { tinggi." }\end{array}$ & C1.1 & 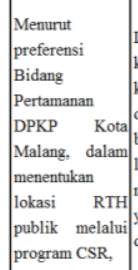 & 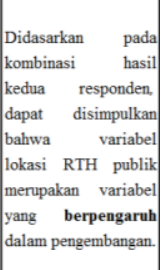 \\
\hline
\end{tabular}

Gambar 3. Kutipan Pemahaman Data pada Variabel Lokasi RTH Publik. Sumber : Hasil Analisis, 2017

Dari uraian transkrip pada tabel pemahaman data tersebut, didapatkan preferensi Pemerintah Kota Malang terhadap pengembangan RTH publik melalui program CSR meliputi :

\section{Lokasi RTH publik}

Diperlukan pemerataan lokasi RTH publik pada lahan potensial di pinggir Kota Malang seperti Kecamatan Sukun, Blimbing, dan Kedung Kandang dengan memperhatikan intensitas masyarakat yang berada disekitar lokasi atau yang melintasi lokasi.

2. Jenis RTH publik

Jenis RTH publik yang perlu dikembangkan melalui program CSR dapat berupa pengembangan taman kota, hutan kota, jalur hijau atau pedestrian sesuai dengan kewenangan Bidang Pertamanan Dinas Perumahan dan Kawasan Permukiman Kota Malang.

\section{Fungsi RTH publik}

Berupa fungsi utama yaitu fungsi ekologis dan fungsi penunjang yang meliputi fungsi sosial budaya, fungsi edukatif, dan fungsi estetika.

\section{Tematik pengembangan RTH publik}

Diperlukan tematik dalam pengembangan RTH publik agar dapat menambah daya tarik visual RTH dan sebagai identitas RTH publik tersebut serta mempengaruhi penyediaan fasilitas didalam RTH publik. Hal ini diwujudkan dengan adanya landmark pada RTH, signage, elemen-elemen penghias dengan desain menarik guna memperkuat tematik yang diangkat dalam pengembangan RTH tersebut.

5. Bentuk bantuan CSR dalam RTH publik

Pemerintah Kota Malang membutuhkan bentuk bantuan CSR berupa skema pembangunan RTH, meliputi pembangunan fisik taman kota, hutan kota, penataan jalur hijau atau pedestrian.

\section{Jangka waktu pemeliharaan}

Pemerintah Kota Malang mewajibkan pihak swasta yang telah membangun RTH publik untuk melakukan pemeliharaan yaitu selama 6 bulan setelah peresmian RTH publik dilakukan.

7. Mekanisme penyelenggaraan program CSR

Dalam mengembangan program CSR dalam bentuk RTH hal yang perlu diperhatikan adalah kemudahan mekanisme kerjasama karena pihak swasta tidak tertarik jika mekanisme penyelenggaraannya dipersulit. Pemerintah juga akan menyiapkan sistem baru dalam pembuatan proposal program.

\section{Bentuk pendekatan pemerintah}

Bentuk pendekatan pemerintah menentukan jumlah swasta yang mau terlibat dalam kerjasama melalui program CSR, seperti Walikota Malang yang memiliki banyak relasi dengan beberapa pengusaha sehingga beberapa perusahaan mau terlibat dalam kerjasama.

9. Kesesuaian program CSR dengan perusahaan

Dalam memilih pihak swasta, Pemerintah Kota Malang harus mempertimbangkan kesesuaian program pemerintah dengan tujuan, visi dan misi serta bidang program CSR dari perusahaan. Perusahaan yang memiliki bidang CSR lingkungan atau pelestarian alam dapat memberikan bantuan berupa pengembangan RTH publik.

\section{Bentuk Insentif Kerjasama}

Bentuk insentif kerjasama itu perlu diberikan kepada pihak swasta yang telah memberikan bantuan CSR, karena hal tersebut merupakan salah satu bentuk apresiasi Pemerintah Kota Malang kepada pihak swasta tersebut. Untuk bentuk insentif kerjasama lain selain plakat tergantung pada perjanjian kerjasama antara kedua belah pihak.

\section{Dampak Program CSR terhadap Perusahaan}

Dengan melaksanakan program CSR berupa pengembangan RTH publik serta adanya nama perusahaan didalam RTH publik maka akan berdampak pada meningkatnya reputasi atau citra perusahaan di mata masyarakat dan dapat berdampak pula pada bisnis perusahaan.

\section{Keterlibatan masyarakat dalam program CSR}

Pemerintah Kota Malang lebih mengoptimalkan pelaksanaan FGD dengan masyarakat yaitu dengan mengundang tokoh masyarakat, masyarakat sekitar yang merupakan target dari pengunjung RTH, LSM, dan akademisi untuk meminimalisir adanya konflik serta terwujudnya pengembangan RTH yang sesuai dengan kebutuhan masyarakat.

\section{Ketersediaan media publikasi program CSR}

Perlu pengoptimalan media publikasi program CSR, karena berfungsi untuk menjaring aspirasi masyarakat, dengan cara jika ada proyek baru pemerintah dapat meng-upload konsep dan desainnya, sehingga masyarakat dapat memberikan masukan.

Selain dari variabel penelitian, didapatkan kebutuhan tambahan dari preferensi Pemerintah Kota Malang dalam mengembangkan RTH publik melalui program CSR, diantaranya adalah :

\section{Kesesuaian dengan tata ruang}

Pemerintah Kota Malang mewajibkan pengembangan RTH publik melalui program CSR yang dilakukan harus sesuai dengan aturan tata ruang yang berlaku.

\section{Pengadaan lahan baru}

Pemerintah Kota Malang harus melakukan pemetaan lahan-lahan potensial untuk dapat dikembangkan menjadi RTH publik terutama pada daerah pinggir kota seperti Kecamatan Sukun, Blimbing, dan Kedung Kandang. 


\section{KESIMPULAN DAN SARAN}

Berdasarkan hasil analisis dan pembahasan yang telah dilakukan dalam penelitian, maka dapat disimpulkan bahwa faktor-faktor kebutuhan pengembangan RTH publik melalui program CSR berdasarkan preferensi Pemerintah Kota Malang meliputi 1) Pemerataan lokasi RTH publik khususnya dipinggir Kota Malang; 2) Jenis RTH publik yang dikembangkan adalah hutan kota, taman kota dan jalur hijau; 3) Pengembangan harus memperhatikan fungsi ekologis dan fungsi sosial budaya; 4) Tematik pengembangan menjadi syarat wajib dalam mengembangkan RTH publik; 5) Pihak swasta wajib melakukan pemeliharaan RTH publik selama 6 bulan setelah peresmian; 6) Bentuk bantuan CSR yang dibutuhkan berupa pembangunan fisik RTH publik; 7) Perlu penyederhanaan mekanisme penyelenggaraan program CSR; 8) Diperlukan pendekatan pemerintah kota kepada pihak swasta agar lebih banyak pihak swasta yang terlibat; 9) Pengembangan RTH publik melalui program CSR dapat dilakukan oleh perusahaan yang memiliki visi misi atau bidang CSR dibidang pelestarian alam; 10) Pemerintah perlu memberikan insentif kerjasama sebagai bentuk apresiasi kepada pihak swasta; 11) Pengembangan RTH publik akan berdampak pada reputasi perusahaan di mata masyarakat; 12) Perlu peran aktif masyarakat seperti tokoh masyarakat, akademisi, dan komunitas; 13) Perlu adanya media publikasi program CSR sebagai wujud branding Kota Malang dan stimulasi kepada pihak swasta lain untuk terlibat dalam kerjasama; dan 14) Pengembangan RTH publik harus sesuai dengan aturan tata ruang yang berlaku.

Saran dari penelitian ini adalah hasil preferensi pemerintah ini perlu disandingkan dengan preferensi pihak swasta agar program CSR yang dijalankan berjalan efektif sesuai dengan kebutuhan antara kedua stakeholder.

\section{DAFTAR PUSTAKA}

[1] Undang-Undang Nomor 26 Tahun 2007 tentang Penataan Ruang. .

[2] Pedoman Penyediaan dan Pemanfaatan RTH di Perkotaan. .

[3] Pemerintah Republik Indonesia, Undang-Undang No. 40 Tahun 2007 tentang Perseroan terbatas. Indonesia, 2007.

[4] Keputusan Walikota Malang No. 188.45/184/35.73.112/2016 tentang Penetapan Taman Kota, Hutan. .

[5] P. K. Malang, Database Program CSR Berupa RTH Publik. [5] Bidang Pertamanan Dinas Perumahan dan Kawasan Permukiman Kota Malang, 2016.

[6] B. Bungin, Analisis Data Penelitian Kualitatif. Jakarta: PT. Rajagrafindo Persada, 2010. 